\title{
Corporate Environmental Management Systems and Outcomes: A Case Study of ISO 14001 Implementation in a Cable Manufacturing Company in Tema, Ghana
}

\author{
Nancy, Botchway (MSc) \\ Shine Francis, Gbedemah (PhD) \\ Wisconsin International University College - Ghana, \\ Department of Development and Environmental Studies, Accra
}

Doi:10.19044/esj.2018.v14n31p320 URL:http://dx.doi.org/10.19044/esj.2018.v14n31p320

\begin{abstract}
The potential for the firm to improve its resource use especially energy management by using Environmental Management Systems (EMS) like ISO 14001 has been shown to be possible. Yet, no in-depth research has been conducted to explore this possibility in Ghana. The implementation of EMS integrates the corporate environmental management strategies and management commitment to sustainable development but most of the organisations in developing countries of West Africa are slow to adopt the management system. The aim of this paper is to assess the drivers, the competitive advantages of ISO 14001 EMS certification and the environmental impact of ISO 14001 EMS certification, in terms of energy consumption. Before and after methods of evaluation were used to analyse the data collected. Purposive sampling technique was used to administer questionnaires and interview guides to employees of the cable manufacturing firm. A review was also made of annual data for electricity consumption before and after ISO 14001 EMS certification. The findings indicate that the main driver of the ISO 14001 EMS certification by the firm is to take advantage of certification to expand its market share. It was also found out that reduction in potential environmental liability risks is the main competitive advantage of ISO 14001 EMS certification. In terms of energy consumption, the findings show that the firm is saving a lot of energy thus cost. It is recommended that more efforts should be made by the energy commission of Ghana through the provision of funds to firms who want to implement environmental management systems.
\end{abstract}

Keywords: Environmental Management System; ISO 14001 Certification; Benefits; Energy Consumption 


\section{Introduction}

A large part of activities that an organization undertakes has some environmental impact, not only in the form of pollution that its activities may cause, but also in the way it uses natural resources, manages its business and produces waste. To address environmental issues and impacts, several tools emerged during the last two decades. Among these tools for environmental management, environmental management systems (EMS) emerged as the befitting response to the global sustainability problems (Ahmad et al., 2009; Zutshi \& Sohal, 2004). Environmental Management System (EMS) can be said to be "a structured framework for managing an organization's significant environmental impacts" (Brady, 2005; 106). Indeed, EMS existed in various forms since the 1970s (Gallagher et al., 2007) but prominence was given to it during the 1980s and beyond because of the Brundtland report of 1987. This prominence came about because of the definition of sustainable development as "development that meets the needs of the present without compromising the ability of future generation to meet their own needs" (WCED, 1987; 43). Sustainability is a systemic approach for the creation and distribution (supply chain) of innovative products and services that minimize resources (inputs such as energy, water, and waste); eliminates toxic substances; and produces zero waste that in effect reduces greenhouse gases like carbon dioxide across the entire life cycle of products and services (Rachuri et al., 2010). Today, several industrial resources of companies are allocated to environmental management (Ahmad et al., 2009) with the sole aim of being sustainable.

Currently, environmental issues have become very important not only in the management of private enterprises but in public organisations as well. Ghana's population is increasing thus leading to an increase in commercial and industrial activities. The conversion of land into agricultural and mining sites is also on the ascendancy. These developments are leading to many environmental problems in the country. The impacts that have been caused by the activities of these business entities are causing local, regional and national changes that the ecosystems cannot easily assimilate. As it is in other parts of the world, business activities and strategies in Ghana are first and foremost geared towards financial performance without attention given to ecological performance (Welford, 1996).

Environmental regulation requirements by the Environmental Protection Agency (EPA) are not just an issue but it goes a step further from stakeholders who are demanding better performance. Environmental costs, which were not factored into firms' activities in Ghana, have become a very important factor for businesses as a result of the awareness that communities, NGOs and the EPA are making in the country. Indeed, these costs cannot be compared to what is happening in North America, Europe and some parts of Asia but there is awareness, and realisation now. 
In line with Steger (1993:155), three types of environmental strategies are employed by businesses in Ghana and the world at large. They are the defensive, preventive, and offensive strategies. Some firms in the country react to environmental problems as they occur without putting in place pollution prevention strategies. This category of firms can be said to employ a defensive strategy and are in the majority in the country. Some firms also focus primarily on preventive strategies. Such companies employ officers (environmental managers) who are specifically in charge of ensuring that the firm's activities are in line with regulation and environmental protection (Bhargava and Welford, 1996). The last category of firms is those that integrate environmental considerations into all stages (life cycle) of product or service design. These stages are from sourcing, production, transportation, use, and postconsumption phases of the product. Here, environmental responsibilities are assigned to all staff of the firm. This category of firms can be said to be employing more offensive environmental strategy (Alexopoulos et al., 2002).

Industries in Ghana and in the world at large are under pressure from several sources, mainly the external market, communities, financial institutions, insurance companies and regulatory bodies both internal and external. Managers and industries are responding to these pressures by developing more comprehensive and more demanding environmental policies (Welford, 1996). Authors like Saarelainen, (1997), Banerjee (1998), and Wilson and Sasseville (1999) have all revealed that environmental issues are being considered in the operations of industries in the developed countries. The objective of this paper is to analyze the competitive advantages derived from ISO 14001 certification and how the firm is cutting down on electricity consumption after certification to ISO 14001.

\section{Benefits firms derive from EMS implementation}

ISO 14000 has been said to be successful and this was attributed to the benefits it offers (Zutshi \& Sohal, 2004). Other authors point out that the benefits to certifying to ISO 14001 EMS include cost reduction, improvement in operational processes, an improved corporate image due to environmentfriendly organizational profile, improved energy, water usage, waste generation and decreased insurance from insurers and financial institutions (Sissell, 2000). These benefits are forcing companies to adopt EMS in their operations but firms in Ghana are not embracing this environmental management system as it should (Gbedemah, 2004). Whilst other companies see ISO 14001 standard as less "rigorous and stringent" than other standards like Responsible Care and EMAS (Zutshi \& Sohal, 2004), others like Post and Altman (1994) see the barriers posed to industries for the adoption of EMS as industrial, due to technical information, capital cost, competitive pressures, 
industry regulations and organizational barriers like employee attitude and inadequate top management support of its adoption.

According to Hewitt \& Gary (1998), certification to ISO 14001 will not instantly benefit the firm however, it will lead to cost savings in energy and water usage and a reduction in waste generation in the short-term. Also, firms stand to gain in the long-term in terms of cost savings especially in environmental control and cleanup of incidents. Kuhre (1995) also confirms certification will not eliminate all cleanup cost, however, it should minimize the number and size of future cleanups. The competitive position of the company will also increase as it will give it an urge over its competitors who do not have the system. Thus, EMS implementation will lead to a more efficient use of natural resources like electricity, water, gas and fuels (Kuhre, 1995). Indeed, the materials and energy required for manufacturing a product may be reduced drastically thereby reducing the product cost, material handling cost, and waste disposal cost which are all increasing these days in the Accra-Tema Metropolitan Area (ATMA).

\section{Methods of the Study}

To measure the firm's environmental performance, the impact on energy consumption was considered. This impact was chosen because previous findings from other studies show that ISO 14001 EMS helps reduce a company's use of natural resources (Arimura et al., 2008; Fei-Baffoe et al., 2013). The research was undertaken by using the mixed method approach. Mixed methods research finds its roots in the 1960s as a concept of combining quantitative and qualitative research methods within the same study (Leech \& Onwuegbuzie, 2009). The study population included all workers, both management and non-management staff of the company. The company has a total population of one hundred and eleven (111) staff. Purposive sampling technique was used to administer questionnaires to forty staff of the company. An interview guide was also used to gather data from the following managers: manager in charge of environmental management, manager in charge of utilities, ISO 14001 internal auditors, health safety and environment representatives, machine operators and some administrative staff. These people were used because it was clearly confirmed that they are all responsible for the continuous improvement of the ISO 14001 EMS and are in the best position to respond to the research questions. To further investigate the impact of the ISO 14001 on energy usage of the company, the managers in charge of Quality Health Safety and Environment (QHSE), and maintenance and performance provided KPI values for electricity consumption and reported waste generated before and after ISO 14001 EMS (2011 to 2016) certification.

No comparison method of evaluation is used. The study takes the form of a before and after design (Campbell and Harper, 2012). These designs 
simply take a measure of the situation before a policy intervention (ISO certification) has been introduced. Here a number of monthly measurements of electricity consumption were taken and compared to the situation afterward. The initial measurements before the certification $(2011,2012$, and 2013) are the baseline years against which subsequent measures assess the change over time. No comparison group studies identify a relationship between the intervention and outcome measures, but it is not possible to say what would have happened anyway. Figure 1 below shows diagrammatic representation of the method.

Figure 1: The Evaluation Method for the study

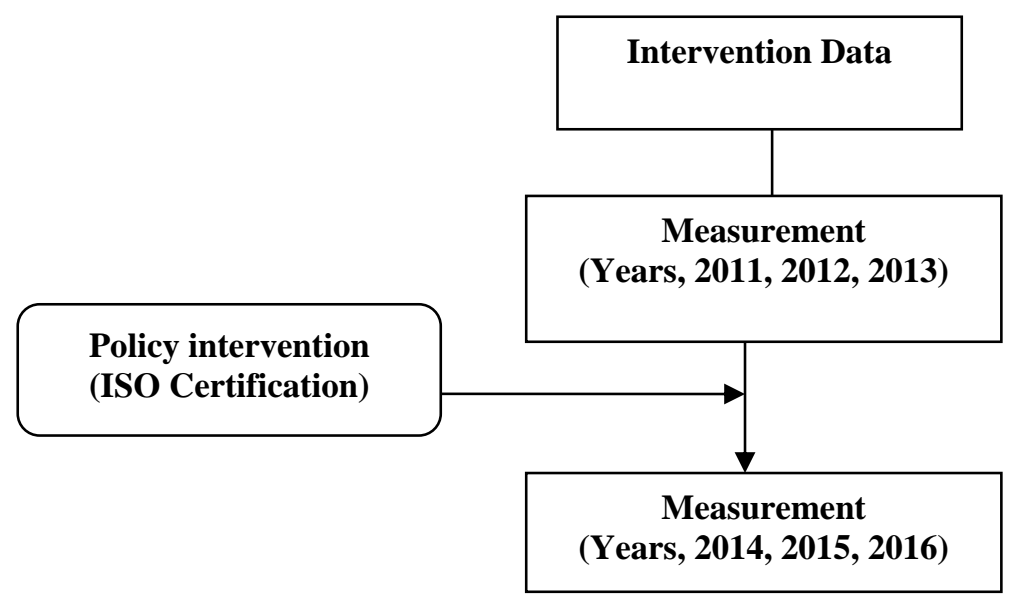

Adapted from Campbell and Harper, 2012

The merit of this method is that it was conducted as part of ongoing performance management, and so it is real-time data thus offering good value for money. The demerit of no comparison method as used in this study is that it is very possible to attribute any measured change to the policy intervention or to understand what would have happened in the absence of the policy. For instance, the change could be the result of factors other than the ISO certification. Despite this demerit, this method is the best because the data gathered are of the highest quality.

In terms of production scrap waste management practices, field visits and investigations were conducted at the various plants, laboratories, offices, and waste dump sites to assess management practices and weigh scrap waste that has been generated. Interaction with management and staff of the firm was also undertaken to determine scrap waste disposal and management practices prior to certification, and after certification to ISO 14001 standard. Analyses and review of past monthly environmental reports (AER) of the company were carried out to derive annual environmental data within the company. The electricity consumed every month in KWh was calculated from 2011 to 2016. 


\section{Results and Discussions}

In this section, the data gathered from the field was analyzed and discussed. The data gathered and collected was then processed in response to the electrical energy consumed every month by the firm. We first present the results in terms of demographic data of the respondents.

\section{Demographic Characteristics of Respondents}

The category of staff that responded to the questionnaire are directly involved in ISO 14001 EMS implementation. An organization's success is not just dependent upon having the right strategy and resources but also reliant upon the ability of its management to harness, direct and support teams and individuals to engage in delivering the organization's mission and objectives of ensuring sustainable development in its operations.

Table 1: Ranks of Respondents

\begin{tabular}{|c|c|c|}
\hline Ranks of respondents & Number & Percentage \\
\hline Assistant Maintenance Manager & 1 & 2.5 \\
\hline Assistant QHSE Manager & 1 & 2.5 \\
\hline Performance Manager & 1 & 2.5 \\
\hline QHSE Internal auditor & 4 & 10 \\
\hline Administrative staff & 7 & 17.5 \\
\hline HSE Representatives & 3 & 7.5 \\
\hline Production supervisors & 3 & 7.5 \\
\hline Other staff & 20 & 50 \\
\hline Total & $\mathbf{4 0}$ & $\mathbf{1 0 0 . 0}$ \\
\hline
\end{tabular}

Source: Fieldwork, 2017

From table 1, one can observe that the firm has appointed a manager solely in charge of performance management to monitor and control the performance of all processes in the plant. The company has also appointed and trained internal auditors from various departments to audit activities based on the certified standards (ISO 14001, OHSAS 18001 and ISO 9001) for the continual improvement of the production process. The organization is required by ISO 14001 standard to direct and support persons to contribute to the effectiveness of the EMS. Again, some employees have been appointed Health, Safety and Environment Representatives for certain processes, departments or sections in the company. The roles and responsibilities of the health and safety (HSE) representatives include; reviewing of environmental and risk register, documenting of environmental and safety performance and assisting to organize safety meetings and addressing SUSA (Safe and Unsafe Acts/ Conditions) issues. Similarly, all employees of the firm have been assigned HSE roles and responsibilities for the continuous improvement of the management system. 
After analyzing the questionnaire for this study, it was observed that 32 respondents representing $80 \%$ were males and 8 respondents representing $20 \%$ were females. The core business of the company is the design and production of cabling systems which transmit electricity and data needed in daily lives. The production activities of the firm require more physical activities such as lifting and manual handling, which is mostly undertaken by men. The few females in the company are found in the following departments and sections: Accounts/Finance, Sales and Marketing, Quality, Health, Safety \& Environment, and Administration and Human Resource department thus the fewer $(20 \%)$ number of female employees in the firm.

\section{Main Drivers of ISO 14001 EMS Certification}

Table 2 shows the results of the main drivers of the ISO 14001 EMS certification at the cable manufacturing company. Market opportunities $(50 \%)$ is the main driver that led to the firm certifying to the EMS. This was followed by regulatory bodies (20\%) like the Ghana EPA who is always on the doors of firms to improve their impacts on the environment.

Firms taking advantage of market opportunities, government and regulatory influences, and institutional and community pressures all influences the way an organization manages its impact on the environment, especially in more developed societies (Massoud, et al., 2010). The results of this paper indicate that majority of the respondents consider market opportunities as the main driver of ISO 14001 certification of the firm. This stems from the fact that population growth, the rising standard of living, urbanization, industrialization in emerging markets, increased mobility, global trade as well as the digital revolution are all generating a huge need for power infrastructure, energy and buildings. Meeting these growing needs with control measures to minimize environmental impact is a challenge the firm shares with its suppliers and customers.

Table 2: Main drivers of the ISO 14001 EMS Certification

\begin{tabular}{|l|c|c|}
\hline $\begin{array}{l}\text { The main driver of ISO 14001 EMS } \\
\text { Certification }\end{array}$ & Frequency & Percentage (\%) \\
\hline Market opportunities & 20 & 50 \\
\hline Government & 4 & 10 \\
\hline Regulatory bodies & 8 & 20 \\
\hline Corporate awareness & 6 & 15 \\
\hline Stakeholders and community pressure & 2 & 5 \\
\hline Total & $\mathbf{4 0}$ & $\mathbf{1 0 0}$ \\
\hline
\end{tabular}

Source: Fieldwork, 2017

Market opportunities attracted $50 \%$ of the responses because the firm deals with three (3) major growth markets in Ghana; mining, oil and gas and building sectors that require ISO 14001 EMS certification prior to any business 
contractual agreement. Some of these companies that the firm deals with are Tullow Oil, Newmont, Chirano, Asanko, Nestlé, DeSimone, Ghana National Petroleum Commission and Electricity Company Ghana Limited, are some of the major customers. The firm is present and desires to maintain its presence at all levels of Oil and Gas production, providing a wide range of energy and telecom cables for onshore and offshore exploration, production and distribution, as well as petrochemical infrastructure. Due to the rate of construction, several trends are emerging among cable customers more often expressed in new expectations and demands. As a builder, promoter, designer, installer, or systems integrator of residential, public and office buildings or industrial plants, major customers of the firm require the completion of documents and other evidence to indicate the company's sustainable use of resources as well as an environmental commitment of top management.

Apart from these reasons, higher market opportunities put companies at a competitive advantage. Companies with high market opportunities often receive better prices from suppliers, as their large orders increase their buying power. Also, increased market opportunities and greater production go together, with the latter decreasing a company's cost to produce an individual unit due to economies of scale. A business can however lose its competitive position in its domestic as well as international markets by failing to pay attention to environmental issues (Chan, 2008). To maintain a customer base and continue to compete in the cable manufacturing industry, the firm prefers to be ISO 14001 EMS certified, and it is now recognized as a company with an Environment Highly Protected (EHP- 2017) certificate. As part of the communication to its stakeholders of being a market leader, one machine operator claimed that "most of the orders received now come from major mining companies like Newmont and Chirano Gold mines. I think the ISO 14001 certification has improved the company's market share".

Also, DiMaggio \& Powell (1983), for example, argue that the managerial decisions to adopt environmental initiatives can be affected by three institutional mechanisms: regulatory, coercive and mimetic. The Assistant QHSE Manager explained that "coercive pressure can be imposed by different external stakeholders, depending on their authority. For example, by means of strict environmental regulations, governing bodies may force companies to adopt environmental practices". The pressures from regulatory bodies come from the threat of penalties and fines for non-compliance, or the request to publish information on the negative environmental impacts of the company (Konar \& Cohen, 1997).

It can be seen from table 2 that, corporate awareness is a main driver of certification and this took $15 \%$ of the responses. The firm on its website, points out that "sustainable development is at the core of its strategy". Some of the most influential drivers of environmental change today are corporate 
awareness of the finiteness of natural resources and the need for maintaining a sense of stewardship and responsibility towards environmental issues (Gavronski et al., 2008). Government, institution and community pressure are among the lowest main drivers for ISO 14001 EMS certification at the firm. The respondent results were $10 \%$ for Government and $5 \%$ for institution and community pressure.

\section{Competitive Advantages derived from ISO 14001 Certification}

Respondents for this study were asked about the competitive advantages derived by the firm from ISO 14001 EMS certification. Table 3 below indicates the responses.

Table 3: Competitive advantages of ISO 14001 EMS Certification

\begin{tabular}{|l|c|c|}
\hline $\begin{array}{l}\text { Competitive advantages of ISO 14001 EMS } \\
\text { Certification }\end{array}$ & Frequency & Percentage (\%) \\
\hline $\begin{array}{l}\text { Improved company reputation and confidence of } \\
\text { stakeholders }\end{array}$ & 6 & $15 \%$ \\
\hline Reduction of waste management cost & 4 & $10 \%$ \\
\hline Increase in market share & 10 & $25 \%$ \\
\hline Reduction in potential environmental liability risks & 8 & $20 \%$ \\
\hline Satisfaction of client environmental requirements & 6 & $15 \%$ \\
\hline $\begin{array}{l}\text { Demonstration of compliance with current and } \\
\text { future statutory requirement }\end{array}$ & 2 & $5 \%$ \\
\hline More efficient use of resources & 4 & $10 \%$ \\
\hline TOTAL & $\mathbf{4 0}$ & $\mathbf{1 0 0 \%}$ \\
\hline
\end{tabular}

Source: Field work, 2017

Findings from this study show that an increase in market share $(25 \%)$ is the most important competitive advantage the firm is deriving from certifying to ISO 14001. A significant competitive advantage is an advantage that organisations gain over their competitors, which provides great value to the customers and a great benefit to the company (Lynch, 2006). Competitive advantage can be gained either by lowering the prices or differentiating the products (Schaltegger, et al., 2003) or combining both strategies. The adoption of a sustainable development strategy has become more important for companies as they cannot only be environmentally friendly but also gain a competitive advantage. To be competitive, the companies need to find an edge in how to control pollution, and to learn continuously, transform and be innovative to reduce the environmental impact, create social value, and to go beyond its competitors (Berzengi \& Lindbom, 2008). Closely related to the increase in market share is the satisfaction of the client's environmental requirement which 15 percent of the respondents mentioned. This is very important to the firm since products are exported to West African market Europe and North America. Indeed, the demand for environmental management practices is very high in the industrialized countries of Europe 
and North America who are the main markets of the firm. The demands from these countries led the firm to get certified to ISO 14001 EMS. Environmental liability is an obligation which may result in future payments for the enterprise due to past events or to compensate a third party harmed by environmental damage of the company. From the increasing incidence of environmental pollution and soil contamination to natural disasters in the form of flood occurring on seasonal to inter-annual basis, the risks posed by the constant interaction between human activities and the environment are diverse. For instance, the Centre for Public Interest Law and Anor, on behalf of the people of Tema Manhean once took Tema Oil Refinery to court in 2007 for being negligent by polluting the Chemu lagoon in Tema. The fact is that it is not only the oil refinery that is polluting the lagoon. Many industries are situated along the industrial enclave including the cable metal manufacturing company that is being studied now. The best insurance against any future environmental liability is to get certified to EMS.

The main area of environmental liability prevention for the firm is in hazardous fuel and oil used in maintenance and production processes. The company has installed underground fuel and oil separators for this storage area. The purpose of the fuel and oil separator is to separate fuel and oil from surface water preventing it from polluting the receiving water as it drains away. The design of the oil and fuel storage area is a requirement by FM Global and in fulfillment of EHP (Environmental Highly Protected) requirement of the firm. FM Global is a Johnston, Rhode Island-based mutual insurance company, with offices worldwide, that specializes in loss prevention services primarily to large corporations throughout the world in the Highly Protected Risk (HPR) property insurance market sector. FM Global is the communicative name of the company, whereas the legal name is Factory Mutual Insurance Company. FM Global engineering personnel regularly visit the firm to evaluate hazards and recommend improvements to their property or work practices to reduce physical and financial risks if a loss occurs. The QHSE Assistant Manager explained that "prior to the discharge of effluent (wastewater from the recycling plant), physicochemical and bacteriological analysis are done to confirm the water quality of the effluent".

\section{Electricity Consumption before and after Certification to ISO 14001}

To further investigate the impact of the ISO 14001 on KPIs of the firm, values for electricity consumption before and after the ISO 14001 certification (2011 to 2016) were used. Knowing how the firm is saving in terms of energy is very important because of the energy crisis in the country. Ghana suffered severe power crisis from February 2013 to December 2015. The power crisis which was locally termed "dumsor" (meaning off-on) dates back to 1983 when a drought resulted in a decrease in the generating capacity of the Akosombo 
Hydroelectric Dam, the main supplier of electricity to the country. The energy crisis in Ghana, occurred again in 2003/2004 and 2006/2007 (Bekoe and Logah, 2013). The situation continue to worsen and this led the authorities responsible for energy distribution coming out with a load shedding or power rationing plan. There was thus the need for the firm to save energy and ISO 14001 became handy, even though it is not the best standard to be used for this purpose but rather ISO 50001. Table 4 below shows energy consumption from 2011 to 2016 of the firm.

Table 4: Annual Electricity Consumption Before and After Certification/KWh (20112013)

\begin{tabular}{|c|c|c|c|c|c|c|c|c|c|}
\hline $\begin{array}{l}\text { Energy } \\
\text { Source }\end{array}$ & 2011 & 2012 & 2013 & TOTAL & \multirow{4}{*}{ 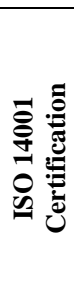 } & 2014 & 2015 & 2016 & TOTAL \\
\hline $\begin{array}{c}\text { National } \\
\text { Grid }\end{array}$ & 977,961 & $1,224,510$ & $1,661,030$ & $\begin{array}{l}3,863,50 \\
1\end{array}$ & & $1,652,276$ & $1,556,876$ & $1,944,788$ & $5,153,940$ \\
\hline $\begin{array}{c}\text { On-site } \\
\text { Generatio } \\
\text { n }\end{array}$ & 26,560 & 19,314 & 9,068 & 294,942 & & 179,957 & 275,269 & 120,082 & 575,308 \\
\hline TOTAL & $1,004,521$ & $1,243,824$ & $1,670,098$ & 4,158443 & & $1,832,233$ & $1,832,145$ & $2,064,870$ & $5,729,248$ \\
\hline
\end{tabular}

Source: Field work, 2017

An effective environmental management system that is based on ISO 14001 will provide firms with a defined structure to allow them to be more confident and effectively manage environmental issues like energy use and their cost-effectiveness. Even though ISO 50001 on energy management has not been certified to by the firm to manage its energy use, ISO 14001 can be said to help this firm. For instance, the total energy consumed from the national grid from 2011 to 2013 before certification was 3,863,501KWh. Adding onsite generation increased the total to $4,158,443 \mathrm{KWh}$. During these years, the firm was operating with only three major production halls. To improve the capacity of the company, various expansion projects were undertaken. One of such major expansion projects was the installation of one extrusion line to add to the already existing two extrusion lines, and the installation of two new drawing machines in addition to the already existing two drawing machines. These major expansions of production processes and equipment were completed in 2013. Thus, from 2014 the firm witnessed an increase in production capacity of about $50 \%$. It is thus expected that energy consumption after certification to ISO 14001 would increase more than two times but this did not happen. Table 4 shows that total energy consumed from 2014 to 2016 was $5,729,248 \mathrm{KWh}$. If production capacity of the firm is increased by about $50 \%$, it is expected that energy consumed would increase from $4,158,443 \mathrm{KWh}$ to about $6,237664 \mathrm{KWh}$ but from the table, one can observe that it was minimal to $5,729,248 \mathrm{KWh}$. A saving of about $508,416 \mathrm{KWh}$ was made. This saving is more than the total on-site generation of 575,308KWh used from 2014-2016. 
The energy crisis affected firms in the country leading to high demand for on-site plants by firms. According to the Association of Ghana Industries (AGI) in its 2014 Business Barometer report, poor and inadequate power supply (energy crisis) is stated as the highest among the top ten challenges affecting businesses in Ghana. Unfortunately, during the energy crisis, manufacturing industries were the most affected due to their reliance on energy generating plants to meet demand. Because of the energy crisis in Ghana, the energy commission embarked on an increased energy conservation drive in the country. For instance, a barn was laid on non-energy efficient products like used refrigerators. Energy management is now a priority for organisations as they all strive to reduce energy waste to meet regulatory requirements and improve their corporate image and cut cost associated with electricity bills. To cut down on cost of energy that the firm used after certification, it followed the procedure laid down by State and Local Energy Efficiency Action Network (2017). The procedure is as follows:

Corporate Commitment: Senior management clearly signalled to staff that improving energy use by the firm is a corporate goal that both plant managers and all staff should care about. This was done through the establishment of clear energy efficiency improvement targets. Plant managers and staff were made accountable for achieving these targets. This point was emphasized by the production supervisors and the performance manager who were interviewed. The lesson here is that corporate commitment and communication of targets is very important for the success of any EMS. In the case of this firm, the corporate commitment was high because of the energy crisis the country was facing which affected production.

Boots were put on the Ground: Competent staff of the firm and outsiders who are experts in ISO 14001 certification and implementation were placed on the ground (facility-level) to continually identify measures to adopt and how to make it realistic. The performance manager said his goal "was to ensure a cut in the amount of energy consumed on site" although he has other tasks of keeping production lines moving. The energy engineer was also very helpful by providing support at the facility.

Efficient Project Processing Systems: Effective internal systems were put in place and they were smoothly operated to allocate financing needed for energy efficient measures deemed to be most advantageous to the company. According to State and Local Energy Efficiency Action Network (2015; 6) "project development and implementation slow when an inordinate amount of time is needed for internal processing of good energy efficiency projects". Because of the energy crisis Ghana faced, it became a priority for the firm to conserve or cut energy used. The company, therefore, set an annual budget for energy and this budget must be met and not exceeded. 


\section{Conclusion}

The Sustainable Development Goal (SDGs) seven sets a target by 2030 to double the global rate of improvement in energy efficiency. The targets set out by the SDGs require an entirely different level of planning, resource allocation, and management if it is to be achieved (Monney \& Ocloo, 2017). This paper aimed at answering the following research questions: What are the main drivers of ISO 14001 EMS certification in the cable manufacturing company? What are the competitive advantages of ISO 14001 EMS certification by the firm? Can the adoption of ISO 14001 EMS certification lead to environmental performance improvement in terms of energy usage?

The results of this paper indicate that majority of the respondents consider market opportunities as the main driver of ISO 14001 certification at the firm. This stems from the fact that population growth, the rising standard of living, urbanization, industrialization in emerging markets, increased mobility, global trade as well as the digital revolution are all generating a huge need for power infrastructure, energy and buildings. Findings from this study also show that an increase in market share $(25 \%)$ is the most important competitive advantage the firm is deriving from certifying to ISO 14001 EMS. To further investigate the impact of the ISO 14001 on KPIs of the firm, values for electricity consumption before and after the ISO 14001 certification (2011 to 2016) were used. Knowing how the firm is saving in terms of energy was very important because of the energy crisis in the country. Major expansions of production processes were completed in 2013 ushering 2014 into an increased production capacity of about $50 \%$. It was expected that energy consumption after certification to ISO 14001 will increase more than two times but this did not happen. The total energy consumed from 2014 to 2016 was $5,729,248 \mathrm{KWh}$. If production capacity of the firm was increased by about $50 \%$, it was expected that energy consumed would increase from $4,158,443 \mathrm{KWh}$ to around $6,237664 \mathrm{KWh}$. However, it was found out that energy consumed was rather $5,729,248 \mathrm{KWh}$. A saving of about $508,416 \mathrm{KWh}$ was made. This saving is more than the total on-site generation of 575,308KWh used from 2014-2016. An effective environmental management system that is based on ISO 14001 provided the firm with a defined structure to allow more confident and effective management of resources.

The main conclusion of this study is that the environmental performance of the company in energy consumption is continually improving after the certification of ISO 14001 EMS because the EMS is implemented alongside key performance indicators and the commitment of top management. The findings of this study support studies by Fei-Baffoe et al., (2013); Ho \& Law (2015); and Ho et al., (2017), which point out that ISO 14001 EMS is a driver for environmental performance improvement. It is thus recommended that the firm communicates its success in ISO 14001 certification to 
stakeholders. This report can be done in the company's brochure or website. This can continually provide more market opportunities and encourage other organisations to implement the ISO 14001 Environmental Management System. The government of Ghana should develop an environmental funding program in collaboration with financial institutions and international funding organisations to assist firms especially small-scale enterprises. This is because as it is in the world at large, "meaningful improvements will require higher levels of financing and bolder policy commitments, together with the willingness of countries to embrace new technologies on a much wider scale" (UN, 2015). This financing will motivate other firms to implement ISO 14001 EMS in the country.

\section{References:}

1. Ahmad S. S., Saha P. K., Abbasi A. and Khan M. (2009), Environmental Management Systems and Sustainability: Integrating Sustainability in Environmental Management Systems, Master's Thesis. Karlskrona, Sweden: Blekinge institute of Technology.

2. Alexopoulos, E., Bialowitz, J., Chtcherbakov, K., Kelley, E., Petroula, T., Tsuji, E., and Zermati, A. (2002), 'Implementation of ISO 14001 in the chemical and pharmaceutical industries in Europe. A comparison of its effectiveness in France, Greece and the Netherlands'. Report number: 2002-3May 2002.

3. Arimura, T.H., Hibiki A. and Katayama, H. (2008), 'Is a Voluntary Approach an Effective Environmental Policy Instrument? A Case for Environmental Management Systems'. Journal of Environmental Economics Management 55:281-295.

4. Banerjee, S. B. (1998), 'Corporate Environmentalism: Perspectives from Organizational Learning', Management Learning, Vol.29, No. 2, Sage publications, U.K.

5. Bekoe, O. E. and Lagah, F.Y.(2013). The Impact of Droughts and Climate Change on Electricity Generation in Ghana, CSIR-Water Research Institute, Accra. Environmental Sciences, 1 (1): 13 - 24.

6. Berzengi, R. and Lindbom, A. (2008). Competitive Advantage of Environmental Sustainability. Bachelor of Arts Dissertation. Halstad, Universitetsadjunkt at the University of Halmstad, Sweden. Available: http://www.diva-portal.org/smash/get/diva2:238560/

FULLTEXT01.pdf accessed on 18/06/2018.

7. Bhargava, S. and Welford, R. (1996), 'Corporate strategy and the environment: the theory', in Welford, R. (ed)(1996), Corporate Environmental Management, Earthscan Publications Ltd., London

8. Brady, J. (ed) (2005). Environmental Management in Organisations: the IEMA Handbook. London: Earthscan. 
9. Campbell S. and Harper G. (2012), 'Quality in policy impact evaluation: Understanding the effects of policy from other influences (supplementary Magenta Book guidance)'. London; HR Treasury/Department of Energy and Climate Change/Department for Environment Food and Rural Affairs.

10. DiMaggio, P. J., and Powell, W. W. (1983). The iron cage revisited: Institutional isomorphism and collective rationality in organizational fields. American Sociological Review, 48, 147-160.

11. Fei-Baffoe B., Botwe-Koomson G., Mensa-Bonso F. I., and Agyapong A. E. (2013), Impact of ISO 14001 environmental management system on key environmental performance indicators of Selected Gold Mining Companies in Ghana. Hindawi Publishing Corporation Journal of Waste Management, Article ID 935843, http://dx.doi.org/10.1155/2013/935843.

12. Gallagher D.R., Andrews R.N.L., Chandrachai A. and Rohitratana K. (2007), Environmental management systems in the US and Thailand: A case comparison. Sroufe, R. and Sarkis, J. (eds.) Strategic Sustainability: The state of the art incorporate environmental management systems. Sheffield: Greenleaf Publishing, pp. 205-22.

13. Gavronski, I., Ferrer, G. and Paiva, E. (2008). ISO 14001 Certification in Brazil: Motivations and benefits. Journal of Cleaner Production, 16: 87-94.

14. Gbedemah, F.S. (2004). Environment Management System (ISO 14001) certification in manufacturing companies in Ghana: Prospects and Challenges, MSc dissertation, Lund University, Lund, Sweden. Retrieved from http://www. lumes. lu. se/database/alumni/03.04/theses/gbedemah_francis. pdf) on 23/07/2018.

15. Hewitt, G. and Gary R. (1998), ISO 14001 EMS Implementation Handbook, Butterworth-Heinemann Ltd, Oxford, U.K.

16. Ho, L.L and Law, P.L (2015). Impact of implementation of ISO 14001 environmental management systems on environmental performance: A case study. International Journal of Engineering Research and Science \& Technology, 4(1):80-90.

17. Ho, L. L., Law, P.L. and Lim, S. F. (2017). Environmental management systems (EMS) adoption in Sarawak (Malaysia): Implementation motivations. Fronteiras: Journal of Social, Technological and Environmental Science 6 (2): 198-216.

18. Konar, S. and Cohen, M. A. (1997). "Information as regulation: The effect of community right to know laws on toxic emissions," Journal of Environmental Economics and Management 32: 109-24. 
19. Kuhre W. L., (1995), 'ISO 14001 Certification-Environmental Management Systems', London, Prentice Hall.

20. Leech N. L. and Onwuegbuzie A. J. (2009), A typology of mixed methods research designs. Quality \& Quantity'. International Journal of Methodology, 43(2): 265-275.

21. Lynch R. (2000). Corporate Strategy, 4th edition, Pearson Education Limited, Harlow, UK.

22. Massoud, M., Fayad, R., El-Fadel, M., and Kamleh, R. (2010). Drivers, barriers and incentives to implementing environmental management systems in the food industry: A case of Lebanon, Journal of Cleaner Production, 18: 200-209, http://dx.doi.org/10.1016/j.jclepro.2009.09.022.

23. Monney, I. and Ocloo, K. (2017). Towards sustainable utilization of water resources: A comprehensive analysis of Ghana's National Water Policy. Water Policy 19 (3): 377-389.

24. Post J. E. and Altman B. W. (1994), 'Managing the environmental change process: Barriers and Opportunities', Journal of Organizational Change Management, 7 (4): 64-81.

25. Rachuri S., Sriram R.D., Narayanan, A., Sarkar, P., Lee, J.H., Lyons, K.W. and Kemmerer, S.J. (2010), Sustainable Manufacturing: Metrics, Standards, and Infrastructure. Workshop Report of National Institute of Standards and Technology, NISTIR 7683.

26. Saarelainen, M., (1997). 'Is this Your Companies' Documentation Pyramid' Cymans Systems International, USA. www.qs9000.com/14_sur.html, (Accessed on 06/05/2018)

27. Schaltegger, S., Burritt, R. and Peterson, H. (2003). An introduction to corporate environmental management: Striving for sustainability, Sheffield, Greenleaf Publishing.

28. Sissell, K. (2000), 'Autos and electronics drive certification'. Chemical Week, 162 (14): 42- 43.

29. State and Local Energy Efficiency Action Network. (2017). Saving energy in industrial companies: Case studies of energy efficiency programs in large U.S. industrial corporations and the role of ratepayerfunded support. Prepared by: Robert P. Taylor, Colin Taylor and Bruce Hedman. U.S. Department of Energy U.S. Environmental Protection Agency

30. Steger, U. (1993), 'The greening of the board room: How German companies are dealing with environmental issues', in: Fischer K. and Schot, J. (1993) (eds), environmental strategies for the industry. international perspectives on research needs and policy implications, Washington: Island Press, p. 147-167. 
31. United Nations (2015). Sustainable development goals. Washington DC, United Nations Department of Public Information.

32. Welford, R. J., (1996). Corporate Environmental Management: Systems and Strategies. Earthscan: London.

33. Wilson W. G. and Sasserville D.R., (1999), 'Sustaining environmental management success: Best business practice from industry leaders, John Wiley and Sons, Inc. USA

34. World Commission on Environment and Development (WCED) (1987). Our Common Future. ( $1^{\text {st }}$ Ed). Oxford University Press, Oxford.

35. Zutshi, A. and Sohal, A. (2004), Environmental management system adoption by Australasian organizations: Part 1 Reasons, benefits and impediments, Technovation, Vol. 24, pp 335-357. http://dx.doi.org/10.1016/S0166-4972(02)00053-6. 